Vol. XXIII No $2 \quad 2017$

\title{
THE INTERNATIONAL IMAGE OF ION I. C. BRĂTIANU IN 1919
}

\author{
Gheorghe CALCAN
}

\author{
Petroleum-Gas University of Ploiești, Romania \\ calcangheorghe@yahoo.com
}

\begin{abstract}
Our paper aims to present how Ion I. C. Brătianu was perceived outside national borders in a very important moment of the Romanian national history, namely the international recognition of the Great Union, within the Peace Conference at Paris-Versailles in 1919-1920. Ion I. C. Brătianu was at that moment Prime Minister and the leader of the Romanian delegation at Versailles. Foreign countries perceived him as a very powerful personality, capable to influence other states with similar interests in Central and South Eastern Europe. Brătianu stoutly and patriotically defended the Romanian interests. Therefore, although his position was correct, it came into conflict with the interests of the great powers. Brătianu would not give up his principles and decided to leave the Peace Conference. French media was objective in their accounts and proved favourable to the Romanian position.
\end{abstract}

\section{Keywords: Ion I. C. Brătianu, image abroad}

\section{Introduction}

The end of the First World War, as well as the consecration of the new geopolitical realities and of the new European territorial configuration, as drawn within the Peace Conference in Paris (1919-1920), represented a milestone for the Romanian diplomacy. In this international context, the Great Union of several Romanian provinces with their motherland was officially recognized [1]. Ion I. C. Brătianu, Prime Minister in office at that time, played an exceptional role in this diplomatic success.

Our paper aims to outline the role Ion I. C. Brătianu had in supporting Romanian national interests within this conference, as perceived on the international level, by several leaders, experts or observers, and especially by French journalists.

\section{The abroad image of Ion I. C. Brătianu in 1919}

On 19 January 1919, Le Figaro announced the official opening of the Peace Conference. Among the participants, there was the Romanian delegation, led by I. I. C.
Brătianu - president of the Council of Ministers [2].

The first exposition I. I. C. Brătianu gave on Romania's rights over the newly united provinces was held in early February, speech that triggered several commentaries in the international press. In the 2 February 1919 issue, Le Figaro showed that in his exposition, Brătianu had presented the claims of Romania "with a warm eloquence and an abundance of arguments", providing details on each Romanian historical province. The publication also noted that the plea of the Romanian Prime Minister made a good impression on the audience [3].

The international press was very much aware of the role Brătianu played in representing the Romanian interests, and, therefore, paid considerable attention to his personality and family lineage. In the context of those debates, there were mentioned the circumstances Romania had entered the war in 1916, the past history of the Romanian nation, and obviously the role of Brătianu.

The author of one of the articles quoted an 
excerpt from his discussion with the Romanian leader, as follows: "My father once asked his grandfather why he had built such a small house. 'It is enough', replied the old man, 'as it is quite likely for it to be destroyed by invaders in the following 20 years'. He answered just like Socrates might have, but for other reasons", remarked the author of the article [4]. The troubled past of the country was entwined with the modesty of the Brătianu family.

The foreign media proved objective in presenting the events, which made it automatically favourable to the Romanian interests, as well as to Brătianu. For example, when presenting the "failure" of 1918, which culminated with the separate peace between Romania and Germany, Le Figaro noted that "Marghiloman Government imposed by Germany had replaced and put in charge the patriot government led by Mr. Brătianu" [4].

In February 1919, when the issue of Banat was being discussed, Brătianu came again to the forefront attention of the international negotiators [1]. The situation repeated three months later when, on 16 May 1919, the conference tackled the issue of the Romanian-Bulgarian border, as well as on several other occasions when the Romanian interests were the topic of official talks. Everyone in Paris knew that Brătianu would not accept proposals that might disadvantage Romania [1]. La France, for example, supported the Romanian point of view and claims on Dobrogea and appreciated the attitude of Brătianu in this respect [5].

The principled policy and energy of Brătianu were highlighted throughout the debates of the Peace Conference. One such moment was the one on 27 May 1919, during the seventh plenary meeting of the Conference. The meeting was aimed at examining the clauses of the treaty with Austria, before the text being handed over to the Austrian delegation. Brătianu became the leader of all allied member states from Central and Eastern Europe. He requested for a 48-hour adjournment, in order to further study the text of that Treaty. The meeting lasted only 25 minutes and was held as a simple dialogue between Clémenceau and Brătianu. Clémenceau accepted the request of the Romanian Prime Minister, considering it "all grounded" and saying that by that delay had been essentially achieved "a simple matter of justice" [6].

During the eighth meeting of the Conference, on 31 May 1919, the strong personality of the Romanian Prime Minister was highlighted even more. He argued Romanian interests with dignity, directly confronting Clémenceau, Prime Minister of France and President of the Peace Conference, US President Wilson and British Foreign Minister Balfour [1]. His arguments and courage were fully observed by the participants. Here is how Aldrovandi Marescotti, eyewitness to this meeting, narrated the event: "3 p.m, at Quai d'Orsay, in the Mirror lounge, a plenary and secret meeting (more than 150 people attend) with the small allied powers, gathered to 'discuss' the peace terms to be submitted to Austria on Monday [...]. Clémenceau is extremely nervous. Brătianu risks a remark on the issue of minority protection clauses, which was equally the concern of Romania. Lloyd George, with an air of discontent, murmures a few words in the ear of Clémenceau: 'This three-fold noodle, stirring so much here was not so zealous during the war'. Brătianu insists and complains that several obligations were imposed on minorities in Serbia and Romania, while in Italy were not. Lloyd George continues in a low voice: 'It is because the Jews are persecuted in Romania, and not in Italy'. Clémenceau replies to Brătianu in a rather harsh and negative manner. Paderewski, Kramarz, Trunbitch speak further. Wilson rises and with his characteristic political, scholar and Presbyterian dogmatic eloquence, though totally insensitive, mimics fair-play and suggests the small powers to accept what the big ones had decided. After Wilson had finished, Clémenceau stood up and asked: 
'Are there any other observations?' And without waiting for a reply, ceased the meeting" [7].

Commenting on the reasons for which Romania did not agree on the treaty with Austria in its original form, one of the authors of the articles from Le Figaro reported the shock of Brătianu when he received the text of this Treaty. "I was, by chance, at Mr. Brătianu when his secretary came and brought a copy of the treaty that was to be given in two days to the representatives of Austria in Saint Germain. He did not hide either his disappointment or dissatisfaction, as he had no reason to be happy. 'I'm afraid', he told me, 'of the material time I need in order to be able to read hundreds of pages, that cover so difficult and complex issues, of which most have a vital interest for my country. How do you think I can take responsibility to notice it and stay quiet?'

The head of the Romanian government immediately drew my attention on the clause of ethnic minorities' protection. In short notice, he made me see all the inconveniences and hazards. Not only that they could interfere with the sovereign rights of a free state, but, under the guise of protecting the foreigners, they could also trigger disorder and incite to riots. 'I will never accept a similar clause', firmly declared Mr. Brătianu" [8]. The quote needs no further comments.

Another episode when the major decision makers of the Peace Conference had to face the principled Brătianu was the one on 11 June 1919, when the Romanian Hungarian borders were to be decided on. Brătianu reproached the great powers the fact they failed to keep the promise made to Romania back in 1916 and settled the new border without consulting Romanian authorities [1].

I. I. C. Brătianu was in the centre of the diplomatic attention once again, on the occasion of the Supreme Council meeting that was to debate the issue of Bessarabia (1-2 July). French media provided detailed information on this moment and on the formal and informal efforts of Brătianu to support this cause [9]. For example, US delegate White noted that "the Romanian minister came to see me a day or two after, and told me that it was time to decide the annexation of Bessarabia to his home country. He wanted to know if we would cooperate in that matter. I repeated what Mr. Lansing had said, namely that I should certainly adhere to that principle" [10]. Immediately after supporting the position of Romania within the above-mentioned reunion, Brătianu left the French capital.

The French press reported this episode as well. On the Romanian Prime Minister leaving both Paris and the Peace Conference, the newspaper Le Temps wrote the following: "Mr. Brătianu, President of the Romanian Council, will leave Paris on Wednesday, heading back to Bucharest" [11]. The reason for this early departure was revealed by Brătianu himelf in an interview with the newspaper Le Matin: "I am leaving because I am convinced that Romania will not accept the terms referring to minorities that are to be incorporated into the treaty with Austria, as they will limit its sovereignty" $[12,6]$.

The same motivation was given in the columns of the newspaper Le Figaro, which stated that the reasons for Brătianu leaving the conference were to be found in the "conditions of the peace treaty with Austria, namely borders insecurity, as well as the obligation imposed to Romania to accept in advance still undetermined stipulations regarding the powers of the minorities and the financial system" [13]. Le Figaro had already announced, under the title Last hour. Mr. Brătianu' Leaving, the decision of the Romanian Prime Minister: "Mr. Brătianu, the president of the Romanian Council and the first Romanian delegate at the Peace Conference, left yesterday evening, at nine, with Simplon Express, bound for Bucharest" [14].

The favourable presentation of the Romanian national interests and of Brătianu's position in the French press did not change in the period following the 
departure of the Romanian Prime Minister, despite the fact that his decision triggered a deep crisis of Romania's relations with the Peace Conference. In early September 1919, Le Figaro posed the question if all ultimatum notes sent from Paris had actually got to Bucharest, and whether it was not the case to first check this before French officials revolt against Brătianu not answering to them [8].

Brătianu clearly caused discomfort to the great powers of the time, due to the fact that he stood up for the national interests, which were sometimes in contradiction with the interests of the decision-makers countries. Queen Maria noticed that "the Tiger", as Clémenceau was nicknamed, did not like Brătianu [15], whereas Spector claimed that the president of the Conference, Georges Clémenceau considered the Romanian leader a very antipathetic politician with a "plaintive voice" [16]. The press from Prahova county appreciated in their turn that the uncomfortable attitude of the Romanian Prime Minister led Clémenceau to stating the following anthological utterance: "In front of Romania, I take off my hat to the ground, but when I have to face Romanians, I shove it on my ears" [17]. The British Prime Minister, Lloyd George, was not delighted to collaborate with Brătianu, as well, feeling bluntly declared: "I would rather meet (instead of Brătianu - our note) Take Ionescu or any other politician that would adhere to the Western view position"[18].

Counterstriking all these acidic considerations, whose motivation is easy to decipher, Sherman David Spector impartially and reasonably stated, when referring to the work of the Romanian Prime Minister that "maybe, no other uncrowned family in Europe ever exercised such an impact on the destiny of their nation and the Brătianu family" [16].

\section{Conclusions}

Our survey highlighted the way Ion I. C. Brătianu's personality was perceived and presented on the international level, during and immediately after the Paris Peace Conference in 1919-1920. We quoted and interpreted the opinions of several state leaders, high officials of the Peace Conference, journalists and eye witnesses to the event.

The portrait one can draw is that of a strong, uncompromising personality, determined to defend the interests of his country to the end. Brătianu defended and invoked the engagements assumed by Western Powers to Romania in 1916, and insisted for the Great Powers in Paris to recognize the Great Union in 1918 and the borders agreed in 1916. He also supported complete independence of his country, which brought him in conflict with postwar interests of the Great Powers. As Brătianu did not give up, he preferred leaving the Peace Conference over compromising his country's interests. Important decision makers obstructed and confronted him, actions to which he reacted by trying to constitute a block of the small and medium states that would oppose the practices of the great powers.

His position was acclaimed by the French press, because it was right. Newspapers such as Le Figaro, Le Matin, almost the entire French press, as well as important segments of the international media, were favourable to Romania. These publications supported the justice of the Romanian cause, showed the efforts made by Romania during the war and revealed several unfair interests of the great powers. Even some of the most important participants in the Peace Conference, challenged and confronted by Brătianu, were obliged to admit his qualities and the fairness of the cause he defended. The personal example of I. I. C. Brătianu can still be considered a raw diplomatic model worth following. 


\section{References}

[1] Calcan, Gheorghe, România în relațiile internaționale ale Conferinței de pace de la Paris-Versailles, 1919-1920. Recunoașterea internațională a Marii Uniri/ Romania in the International Relations within the Peace Conference in Paris-Versailles, 19191920: International Recognition of the Great Union, Cluj Napoca, Mega Publishing House, 2013, pp. 83 -87, $111-115,123$-124, 162 -165.

[2] Autur de tapis vert, „Le Figaro”, 19 janvier 1919.

[3] Raymond Recouly, Les revendications de la Roumanie, „Le Figaro”, 2 févriere 1919.

[4] Denys Cochin, Pour la Roumanie, „Le Figaro”, 15 juine 1919.

[5] Ad hoc, Evenimentele, „Lanterna”, an I, 28 iulie 1919.

[6] Brătianu, Gheorghe I., Acţiunea politică şi militară a României în 1919, în lumina corespondenţei diplomatice a lui I. C. Brătianu/ The Political and Military Actions of Romania in 1919, as Reflected in the Diplomatic Correspondence of I. C. Brătianu, Second edition, revised and supplemented, Bucharest, Cartea Românească Publishing House, 1940, pp. 44-46, 103.

[7] Marescotti, Aldrovandi L., Guerre diplomatique, 1914-1918, Paris, Gallimard, Page 341.

[8] Raymond Recouly, La Conférence et les roumaines, „Le Figaro”, 5 septembre 1919.

[9] La question de Bassarabie, „Le Temps”, 4 juillet, 1919.

[10] Țurcanu, Ion, Unirea Basarabiei cu România. Preludii, premise, realizări/ The Union of Bessarabia with Romania: Background, Premises, Materializations, 1918, Chișinău, Tipografia Centrală, 1998, p. 339.

[11] Dans les Balcans. Crise ministerielle en Roumanie, „Le Temps”, 3 juillet, 1919.

[12] Bold, Emilian, De la Versailles la Lausanne, (1919-1932). Activitatea diplomaţiei româneşti în problema reparaţiilor de război (Contribuţii)/ From Versailles to Lausanne, (1919-1932): Diplomatic Romanian Activity with Respect to War Compensations, Iaşi, Junimea Publishing House, 1976, p. 20.

[13] Le départ de M. Bratiano, „Le Figaro”, 4 juillet, 1919.

[14] Dernière heure. Départ de M. Bratiano, "Le Figaro", 3 juillet, 1919.

[15] Regina Maria a României, Capitole târzii din viața mea, Memorii redescoperitel Queen Mary of Romania: Late Chapers of My Life: Unveiled Memoirs, Bucharest, Alfa Publishing House, 2007, p. 30.

[16] Spector, Sherman, David, România și Conferința de Pace de la Paris. Diplomația lui Ion I. C. Brătianu/ Romania and Peace Conference in Paris: The Diplomatic Activity of Ion I. C. Brătianu, Iași, Institutul European, 1995, pp. 3, 138.

[17] Tomescu, Gogu, (avocat), Constatări/ Remarks, „Lanterna”, an I, nr. 25, 30 iunie 1919.

[18] Campus, Eliza, Recunoaşterea pe plan internaţional a desăvârşirii unităţii statale a României/ The International Recognition of the Great Union Completion, „Studii”/ Studies, tom. XXI, nr. 6, p. 1174, 1968. 